\title{
Permanence of professionals who work in the Tuberculosis Control Program
}

\author{
Permanência de profissionais que atuam no programa de controle da tuberculose \\ Permanencia de profesionales que actúan en el Programa de Control de la Tuberculosis
}

Danielle Galdino de Paula'

ORCID: 0000-0002-0103-6828

Alexandre Sousa da Silva'

ORCID: 0000-0002-5573-4111

Tereza Cristina Scatena Villa"

ORCID: 0000-0001-8927-2624

Maria Catarina Salvador da Motta'

ORCID: 0000-0002-3278-5645

'Universidade Federal do Rio de Janeiro. Rio de Janeiro, Brazil. "Universidade de São Paulo. Ribeirão Preto, São Paulo, Brazil.

How to cite this article:

Paula DG, Silva AS, Villa TCS, Motta MCS. Permanence of professionals who work in the Tuberculosis Control Program. Rev Bras Enferm. 2019;72(5):1258-64. doi: http://dx.doi.org/10.1590/0034-7167-2017-0403

Corresponding Author:

Danielle Galdino de Paula E-mail:danigalpa@gmail.com

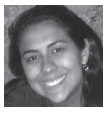

Submission: 06-05-2017

Approval: 04-21-2018

\begin{abstract}
Objective: To analyze the length of stay of the professionals who work in the Tuberculosis Control Program in Basic Health Units of the city of Rio de Janeiro/RJ. Method: Sectional study, developed in eight Health Units of the Maré Complex/RJ. Physicians, nurses, nursing technicians and Community Health Agents of the Family Health Teams were interviewed. The Kruskal-Wallis test was used to verify the existence of groups with the same distribution, and Dunn's multiple comparison test with Bonferroni correction, to identify which group presented a difference. Results: Among Health Units, a significant difference was observed in the length of work ( $\mathrm{p}$-value = $0.0005909)$ and in the dwell time ( $p$-value $=0.0003598)$. Conclusion: It was observed low length of stay of the professionals that work in the Basic Health Units. This result points to challenges inherent in the control of tuberculosis at the local level.

Descriptors: Tuberculosis; Family Health Strategy; Health Centers; Health Personnel; Continuity of Patient Care.
\end{abstract}

\section{RESUMO}

Objetivo: Analisar o tempo de permanência dos profissionais que atuam no Programa de Controle da Tuberculose em Unidades Básicas de Saúde do município do Rio de Janeiro/RJ. Método: Estudo seccional, desenvolvido em oito Unidades de Saúde do Complexo da Maré/RJ. Entrevistaram-se médicos, enfermeiros, técnicos de enfermagem e Agentes Comunitários de Saúde das Equipes de Saúde da Família. Optou-se pelo teste de Kruskal-Wallis para verificar a existência de grupos com a mesma distribuição, e teste de comparações múltiplas de Dunn, com correção de Bonferroni, para identificar qual grupo apresentava diferença. Resultados: Entre as Unidades de Saúde, comprova-se diferença significativa no tempo de exercício da função ( $p$-value $=0,0005909$ ) e no tempo de permanência ( $p$-value $=0,0003598$ ). Conclusão: Constatou-se baixo tempo de permanência dos profissionais que atuam nas Unidades Básicas de Saúde. Esse resultado aponta para desafios inerentes ao controle da tuberculose em nível local. Descritores: Tuberculose; Estratégia Saúde da Família; Centros de Saúde; Pessoal de Saúde; Continuidade da Assistência ao Paciente.

\section{RESUMEN}

Objetivo: Analizar el tiempo de permanencia de los profesionales que actúan en el Programa de Control de la Tuberculosis en Unidades Básicas de Salud del municipio de Río de Janeiro/RJ. Método: Estudio seccional, desarrollado en ocho Unidades de Salud del Complejo de la Maré/RJ. Entrevistaron médicos, enfermeros, técnicos de enfermería y Agentes Comunitarios de Salud de los Equipos de Salud de la Familia. Se optó por la prueba de Kruskal-Wallis para verificar la existencia de grupos con la misma distribución, y prueba de comparaciones múltiples de Dunn, con corrección de Bonferroni, para identificar qué grupo presentaba diferencia. Resultados: Entre las Unidades de Salud, se comprueba diferencia significativa en el tiempo de ejercicio de la función ( $p$-value $=0,0005909$ ) y en el tiempo de permanencia ( $p$-value $=0,0003598$ ). Conclusión: Se constató bajo tiempo de permanencia de los profesionales que actúan en las Unidades Básicas de Salud. Este resultado apunta a desafíos inherentes al control de la tuberculosis a nivel local.

Descriptores: Tuberculosis; Estrategia Salud de la Familia; Centros de Salud; Personal de Salud; Continuidad de la Atención al Paciente. 


\section{INTRODUCTION}

Created to meet the constitutional objectives of the Brazilian Unified Health System (SUS - Sistema Único de Saúde), the Family Health Strategy (FHS) proposes to act on the social determinants of health at all levels of care through integrated actions to promote health and prevention, care, cure and rehabilitation of health conditions ${ }^{(1)}$.

Since the implementation of the model of expansion of Primary Care in the city of Rio de Janeiro, in Rio de Janeiro State, Family Health coverage increased from 3.5\% in January 2009 to $46.8 \%$ in March. 2015 , with a predominance of distribution of Units with secondary/ tertiary care profile in the municipality $(53.2 \%)^{(2)}$.

The FHS expansion project faces numerous difficulties in the city of Rio de Janeiro, including some specific restrictions, such as inadequate physical, human and financial infrastructure. However, it is necessary to consider the adherence of professionals working in the FHS to the actual fulfillment of the established proposals. Among the inherent incentives for adherence, we can list stable and legally protected employment relationships, salary incentives and adequate infrastructure ${ }^{(3)}$.

The long-term relationship between professional and users is one of the characteristics of the FHS. Therefore, reflecting on the length of stay of professionals working at the FHS and their correlation with the chronicity of certain diseases, such as tuberculosis, is relevant, since the long-term relationship is an essential condition in the implementation of public programs related to chronic conditions.

Incorporated in all Health Units of the Maré Complex (Type of favela located in the city of Rio de Janeiro), the largest set of favelas (A favela Brazilian Portuguese for slum, is a low-income historically informal urban area in Brazil) in the northern part of the city of Rio de Janeiro ${ }^{(4)}$, the Tuberculosis Control Program faces challenges, since the region presented the highest dropout rate of treatment between the period 2012 and $2013^{(2)}$. Thus, it is necessary to consider the permanence of professionals for the real fulfillment of the proposals established in the Tuberculosis Control Program.

Therefore, this study aims to analyze the length of stay of the professionals who work in the Tuberculosis Control Program in Health Units of the city of Rio de Janeiro.

Based on the analysis, it is sought to measure the extent to which the health professionals' permanence in the Basic Health Units can affect the tuberculosis control actions at the local level. The relevance of this discussion to the country's health policy stems from the need for the expansion of the FHS and tuberculosis control actions to be linked to trained professionals who stay longer in health services, corroborating the principle of longitudinality.

\section{OBJECTIVE}

To analyze the length of stay of the professionals who work in the Tuberculosis Control Program in Basic Health Units of the city of Rio de Janeiro.

\section{METHOD}

\section{Ethical aspects}

In compliance with Resolution 466/12 of the National Health Council (Conselho Nacional de Saúde), which deals with research involving human beings, the project of this study was submitted to the Research Ethics Committee of the Universidade Federal do Rio de Janeiro and, later, to the Ethics Committee of the Municipal Health Office of the Municipality of Rio de Janeiro. The study was approved by both institutions.

Each individual interviewed was approached by the researchers, who explained the nature and the objectives of the study and requested their participation by signing the Informed Consent Form.

\section{Design}

This is a sectional, descriptive and quantitative study.

\section{Place of study and period}

The study setting was all Health Units located in the territory of the Maré Complex, in the city of Rio de Janeiro, totaling eight Health Units. Data collection was performed from November 2013 to April 2014.

The choice of the setting is allied to the social peculiarities that sharpened the present study, since the Maré Complex has the largest number of inhabitants among the ten largest favelas located in the northern part of the city of Rio de Janeiro $\left(129,770\right.$ inhabitants) ${ }^{(5)}$. The setting is also justified by the fact that the Health Units located in the Maré Complex had approximately 204 cases of tuberculosis between January 2012 and July 2013, and 26.9\% of the patients abandoned treatment ${ }^{(2)}$.

In May 2009, the Municipal Health Office of Rio de Janeiro (MHO$\mathrm{RJ})$ presented the proposal of the FHS in creating the Family Clinics, which aim to offer structure, resources and inputs to offer quality care to the population. As for the structure, the Health Units of Rio de Janeiro are classified into three models: a) Type A units: Basic Health Units composed only of FHS teams; b) Type B units: Basic Health Units of the Municipal Health Center, with the incorporation of one or more FHS teams; and c) Type C units: Traditional Basic Health Units, where there is no presence of Family Health Teams. In this study, three Health Units were Type A and five were Type $B^{(6)}$.

\section{Population}

The research population consists of professionals who worked in the Family Health Teams of the eight Health Units of the Maré Complex that served as the setting for the present study, including physicians, nurses, nursing technicians and Community Health Agents. For the calculation of the minimum sample, we considered: sample error of 0.05 , confidence interval of $95 \%$ and $\mathrm{P}$ (population ratio) of $50 \%$. The calculation of the sample was obtained with reference to the total population of health professionals who worked at the FHS of the Units investigated at the Maré Complex in the year 2013. After the sample calculation, a minimum sample of 171 professionals to be interviewed was obtained. From this calculation, proportional sharing was defined to determine the number of professionals per category that would be interviewed in the Health Units. The following result was obtained: 19 nurses, 19 physicians, 19 nursing technicians and 114 Community Health Agents.

\section{Inclusion and exclusion criteria}

The following inclusion criteria were determined: being a professional working in health services and having provided assistance, 
at least once, to tuberculosis patients in the Basic Health Unit where they currently work or in another where they have already developed work and care actions to the tuberculosis carrier.

The exclusion criterion eliminated professionals who worked exclusively in Type C (Health Units without Presence of Family Health Teams).

\section{Study Protocol}

A questionnaire titled "Assessment of Chronic Illness Care $(\mathrm{ACIC})^{\prime \prime(7)}$, adapted and validated for the control of tuberculosis in 2014, was used, which, in addition to evaluating the Chronic Conditions Attention Model (MACC - Modelo de Atenção às Condições Crônicas) and the qualification of attention to chronic conditions in Primary Health Care, contains questions of completion regarding the length of work and the time of the professional's stay in the Health Unit. To complement the research, a Field Diary created for immersion in the local reality of each Basic Health Unit, allowing more discussion about the results found. The Field Diary consisted of observations regarding Directly Observed Treatment, follow-up of records on treatment evolution and follow-up of cases (beginning and end of treatment) and observations on human resources/team that accompanies cases of tuberculosis in the Basic Health Unit.

\section{Analysis of results and statistics}

The analysis of variables length of stay and work was described in months. The data analyzed were tabulated in the Microsoft Excel $2013^{\circledast}$ Program and later analyzed in the $\mathrm{R}^{\otimes}$ Program 3.1.1. To reach the objective, we used the exploratory analysis of the variables by means of graphs and descriptive measures. After verification of non-adherence to the normal distribution (Shapiro-Wilk test), we chose the Kruskal-Wallis test to verify the existence of statistically significant differences between the groups. A significance level of $5 \%$ was used and, therefore, when rejecting the null hypothesis (p-value $<0.05)$, it was concluded that at least one of the groups presents different behavior from the others. To identify the group in which there were differences, Dunn's multiple comparison test was used, with Bonferroni correction.

\section{RESULTS}

The distribution of the variables was asymmetric and, after the normality tests, it was contacted that the variables were not considered normally distributed. Therefore, we have chosen non-parametric tests.

We interviewed 174 health professionals, 18 (10.3\%) physicians, 21 (12.1\%) nurses, 20 (11.5\%) nursing technicians and 115 (66.1\%) Community Health Agents (CHA).

The distribution of the length of work of professionals among the Health Units presented a significant difference ( $p$-value = 0.0005909 ). The unit where the professionals have less length of work presented mean of 28.5 months, and the Health Unit where the professionals have greater length of work presented mean of 143.5 months, as can be seen in Table 1 As for the Type A units, the Health Unit 1 differs statistically from the others. In relation to Type B Units, Health Unit 8 differs from the others.

In relation to schooling, the length of work between graduates (physicians and nurses) and undergraduates (nursing technicians and CHA) presented a significant difference $(p$-value $=0.02041)$.

There was no significant difference in relation to the professional length of the health professionals working in Type A units ( $p$-value $=0.05534)$. In these units, graduate professionals have a mean time of 115.4 months, and the undergraduate ones, 72.79 months. In these Units, no difference was observed in the length of work s in relation to professional categories. However, physicians have longer professional length of the function (mean: 174.7 months). Nursing technicians have time of work of 86.77 months, while nurses and CHA have mean time of work of 70.92 and 70.23 months, respectively.

Table 1 - Time of work per Health Unit, Professional Category and Schooling - between types of Health Units (A and B) - Maré Complex, Rio de Janeiro, Brazil, 2014

Type A - Mean (Standard Deviation)

Type B - Mean (Standard Deviation)

Health Units

Mean* (Standard Deviation)

$p$ value $=0.0005909$
Professional Category

$p$ value $=0.0001858$ $p$ value

Physician

Nurse

Nursing Technician

Community Health Agents
$81.3(73.85)$

$\mathrm{HU} 1$ a

85.71 (78.25)

$\mathrm{HU} 2^{\mathrm{b}}$

28.5 (18.29)

$\mathrm{HU} 3^{\mathrm{a}}$

96.38 (92.23)

$\mathrm{HU} 4{ }^{\mathrm{a}}$

82.35 (58.04)

$\mathrm{HU} 5^{\mathrm{a}}$

94.48 (79.14)

0.007614

174.7 (139.82)

$70.92(42.25)$

86.77 (65.20)

70.23 (59.92)
102 (92.19)

HU $6^{\circ}$

$143.5(108.84)$

$\mathrm{HU} 7^{\mathrm{b}}$

75 (91.13)

$\mathrm{HU} 8^{\mathrm{a}}$

85.52 (49.95)

0.005289

$248(143.12)^{b}$

$104(79.14)^{a}$

$114.9(74.89)^{\mathrm{a}}$

$69.73(46.11)^{\mathrm{a}}$ 


\begin{tabular}{|c|c|c|c|}
\hline & & Type A - Mean (Standard Deviation) & Type B - Mean (Standard Deviation) \\
\hline & $p$ value & 0.08316 & 0.002509 \\
\hline Schooling & Graduate & $115.4(107.56)$ & $176(134.44)$ \\
\hline \multirow[t]{2}{*}{$p$ value $=0.02041$} & Undergraduate & $72.79(60.65)$ & $75.92(52.42)$ \\
\hline & $p$ value & 0.05534 & 0.00414 \\
\hline
\end{tabular}

Note: * Mean informed in months. Letters " $a$ " and " $b$ " mean groups that have presented a difference.

In Type B units, mean time of work between graduates and undergraduates presented a significant difference $(p$-value $=$ 0.00414). In these Units, the graduates have more length of work (176 months). The physicians also had a longer period of profession (mean: 248 months), followed by nursing technicians (mean: 114.9 months), nurses (mean: 104 months) and CHA (mean: 69.73 months) Table 1.

Regarding the length of stay of health professionals, there was a statistically significant difference ( $p$-value $=0.0003598$ ) between Type A and Type B Health Units in the Maré Complex. In the Type A Units, a statistical difference was observed between the length of stay of health professionals ( $p$-value $=0.0001246$ ). It should be noted that, among the units of type A, Health Unit 2 shows different behavior from the other units, with a mean length of stay of 17.93 months. Among Type B units, there was no statistically significant difference ( $p$-value $=0.2434$ ).

As for the professional category, the residence time in the Type A units presented a statistically significant difference $(p$-value $=$ 0.3388). Physicians and nurses are the least time-consuming professional categories in type A units ( $m e a n=21.78$ months and 48.92, respectively). In type $B$ units, residence time does not differ between professional categories ( $p$-value $=0.1019$ ), as shown in Table 2 .
Regarding schooling, a significant difference was observed between Type A and Type B units ( $p$-value $=0.002601$ ). Graduates have different behavior from undergraduates, and in both type A and type B units, graduates remain in mean less time than undergraduates.

\section{DISCUSSION}

Projects have been carried out by the Municipal Health Office of Rio de Janeiro in order to ensure the implementation of basic infrastructure, public facilities and levels of accessibility satisfactory for the so-called urbanized favelas, which, according to the Municipal Housing Office, are those that have urban development programs such as Favela - Neighborhood (case of Maré), Bairrinho, Growth Acceleration Program (PAC - Programa de Aceleração do (rescimento) and similar ${ }^{(9)}$.

Although this study does not aim to investigate the reasons related to the low permanence of the health professionals, which would only be possible with the qualitative analysis of each report of the professionals, the low permanence of professionals graduated in Primary Health Care services was reported in previous studies, which was verified based on a literature review.

Table 2 - Length of stay per Health Unit, Professional Category and Schooling - between types of Health Units (A and B) - Maré Complex, Rio de Janeiro, Brazil, 2014

Type A - Mean (Standard Deviation) Type B - Mean (Standard Deviation)

Health Units

Mean* (Standard Deviation)

$p$ value $=0.0003598$

$\begin{array}{ll} & p \text { value } \\ \text { Professional Category } & \text { Médico } \\ p \text { value }=0.9741 & \text { Enfermeiro } \\ & \text { Técnico de Enfermagem } \\ & \text { Agente Comunitário de Saúde } \\ & p \text { value } \\ \text { Schooling } & \text { Graduados } \\ p \text { value }=0.002601 & \text { Não Graduados } \\ & p \text { value }\end{array}$

pvalue
Médico
Enfermeiro
Técnico de Enfermagem
Agente Comunitário de Saúde
$p$ value
Graduados
Não Graduados
$p$ value

Note - *Mean informed in months. Letters " $a$ " and " $b$ " mean groups that have presented a difference.

$\begin{array}{cc}58.77(55.03) & 54.29(44.32) \\ \text { CMS US1 }{ }^{\mathrm{a}} & \text { US } 6 \\ 66.29(59.2) & 47.5(48) \\ \text { CMS US2 } & \text { US } 7 \\ 17.93(12.34) & 62(47.56) \\ \text { CMS US3 } & \text { US } 8 \\ 68.95(70.03) & 53.24(36.05) \\ \text { US } 4^{\mathrm{a}} & \\ 81.88(52.77) & \\ \text { US 5 } & \\ 41.35(35.39) & \\ 0.0001246 & \\ 21.78(15.62)^{\mathrm{b}} & 0.2434 \\ 48.92(53.38)^{\mathrm{a}} & 46.11(53.96) \\ 85.38(68.05)^{\mathrm{a}} & 42.67(42.37) \\ 60.25(53.38)^{\mathrm{a}} & 31.57(22.12) \\ 0.03388 & 61.95(44.45) \\ 37.3(43.06) & 0.1019 \\ 64.14(56.68) & 44.39(47.09) \\ 0.02041 & 57.78(43.24) \\ & 0.005604\end{array}$


In the present study, we observed a statistically significant difference in the length of stay of health professionals working in the Type A Basic Health Units, which are units exclusively with FHS teams. This result may be associated with the insertion of the Family Clinics in the city of Rio de Janeiro, in May 2009, when there was more investment in the Basic Health Units with the exclusive presence of the FHS. Authors corroborate that the FHS expansion in the city of Rio de Janeiro was followed by different periods. In April 2009, the period of recovery of the Family Health Teams was observed, reaching the number of 149 Teams. In a second period, known as ascension, between May 2009 and February 2010, the number of Teams reached 173. In a period of frank rise, which runs from May to December 2010, called expansion, there were significant increase of the Teams ${ }^{(10)}$.

However, in spite of the expansion of the FHS, graduates, compared to undergraduates, spend less time in Health Units (although the latter are part of a group that also cares for people with tuberculosis). Patients with tuberculosis (and communicants of patients with tuberculosis) need the qualification of professionals who provide assistance in the search for active search, diagnosis, treatment and adherence. This fact places the treatment of tuberculosis in a long-term relationship between professionals, patients with the disease and family members.

The low time of permanence of the graduated professionals generates concern, after all, the scientific evidence points to a serious crisis of work situation of the professionals working within the scope of the Brazilian Unified Health System. Among the main factors of rotation indicated in the studies, the following stand out: the precariousness of the work link, the salary issue, the fragmentation of the training of professionals, the style of authoritarian management and the poor working conditions ${ }^{(11)}$. This data conditions for the demotivation, "lack of responsibility" in the execution of activities - for example, non-compliance with the workload - and abandonment of work ${ }^{(12)}$. Research conducted in the State of Minas Gerais/Brazil showed that the work environment at FHS is characterized by a focus on productivity growth, represented by the division of tasks, collection by results and control and imposition of work rhythm ${ }^{(13)}$. This finding seems to reinforce the idea that the organizational mechanisms of Primary Health Care lack strategies to capture and stay these professionals in the health services.

The training of the professionals is of great relevance for the learning and improvement of the daily relations of the health services, mainly the team work and the contact with the patient of tuberculosis, a relation that is of long duration. When you are in a state with a growing population and high tuberculosis incidence rates, the pathways related to disease control measures are in the qualification of future health professionals and in the reorientation to the Primary Care model.

Corroborating the findings, a study that addressed the knowledge of medical students in an American institution emphasized the need to direct knowledge to the Primary Care model ${ }^{(14)}$. In a survey conducted in the city of Brasilia/Brazil, the discourse of many health professionals and managers who work at the FHS follows the hospital-centered model. The results point to the lack of professionals who have knowledge about Primary Care ${ }^{(15)}$. A similar result was reported in a review article which showed that, despite FHS advances, some professionals persist in maintaining standardization in epidemiological assistance, which inhibits the operation of an innovative work process based on the real need of the population, not limited in the performance of procedures ${ }^{(16)}$.

The research team was faced with a relevant fact: despite the fact that the complete composition of the FHS teams in the National Record of Health Establishments (CNES - Cadastro Nacional de Estabelecimentos de Saúde), in two Health Units there was a availability of physicians in relation to the days and times of the week for tuberculosis cases. In a Health Unit, the professional deficit (Community Health Agent) entailed internal relocation in order to supply the affected micro-area. It was observed that the relocation occurred as long as there was no interference in the continuity of treatment in the Professional's Team.

The use of the health surveillance model, from the perspective of an area of coverage, assists in the effectiveness of the work process of the Family Health Teams, since it makes it possible to intervene in a specific situation for a given population group. It is then assumed that expanding the Family Health Teams is synonymous with the expansion of health interventions ${ }^{(17)}$.

In the present study, it is verified that the relocation of health professionals causes work overload, a fact observed in the Units studied, making it difficult to perceive the needs not directly related to the disease of patients with tuberculosis who are being treated. Even with the addition of Teams over the years in the Family Clinics of the city of Rio de Janeiro, the Team deficit is still present. This deficit may prevent health promotion actions and the prevention, recovery and rehabilitation of diseases and diseases in their entirety.

The research team was faced with frequent shootings in the region, which also led to the suppression of essential services, such as electricity. It is emphasized that sometimes the research team and professionals who did not live in the community were prevented from entering the Health Units or leaving them due to shootings between criminal factions and the police.

The Maré Complex is among the most populous favela-neighborhood in the city of Rio de Janeiro, with about 130 thousand inhabitants ${ }^{(5)}$. The area has one of the lowest per capita incomes in the city of Rio de Janeiro and low human development indicators $^{(9)}$. The absence of public power in matters of public security and the presence of three criminal factions in the study setting led to a "division" of the region outside the sphere of the state. Each of the sub-regions is "managed" by a different group of drug traffickers. Linked to this last indicator, elements such as violence, determinants and health determinants and "planned" absence of public power in many configurations requires a "training" of the professional that goes beyond the academic training. This situation was also illustrated in a study carried out in the area of Planning 1.0, a region that involves central districts of the city of Rio de Janeiro ${ }^{(18)}$. In that study, the authors concluded that the violence dimension in the communities makes difficult the treatment of tuberculosis, since it prevents the entrance and exit of home visitors. The results demonstrate that, in order to carry out the Directly Observed Treatment in the poor communities, the Health Team uses strategies of agreement with the leaders of the traffic, police and patients, aiming to guarantee the supervision of the treatment of tuberculosis. 
Studies corroborate the need for intersectoral actions in partnership with the available support and social networks, as well as other governmental instances ${ }^{(19)}$. The FHS is an integral part of the dialogue between different actors and settings regarding the control of tuberculosis, since, as it is based on local reality, the planning of strategies is directed to the reality of the patient and the family(20).

\section{Study limitations}

The study presents limitations since it was based only on the perception of the health professionals of the Health Units of the Maré Complex. Therefore, new evaluations would be important in order to evaluate the progressive expansion of FHS based on the evaluation of the length of stay of professionals who work in other Health Units of the city of Rio de Janeiro.

\section{Contributions to the sectors of Nursing, Health or Public Policy}

The study contributes to public health policies since some of the weaknesses pointed out in the variables evaluated in the study may help identify the areas that need improvement for tuberculosis care. The results demonstrate the need for a better understanding of Primary Health Care Teams (nurses, physicians, health professionals and managers) on agreed goals (and their actual implementation) based on the length of stay of professionals working at the FHS, more specifically, professionals who work in the Tuberculosis Control Program.
For Nursing, the FHS, as a "restructuring" model, has provided an important reordering in the care model in the Brazilian Unified Health System. The long-term permanence of Nurses is demonstrated positively in evidence related to the Tuberculosis Control Program and in the main indicators of the populations assisted with this disease.

\section{CONCLUSION}

In the present study, the length of stay of graduate professionals (physicians and nurses) was inferior to that of the undergraduate professionals (nursing technicians and Community Health Agents). Factors that discourage practitioners from remaining active in the FHS in this community may be numerous. However, due to the temporality of tuberculosis treatment, the study demonstrates the need for managers to develop strategies to capture and fix these professionals in the work environment and effective support from other levels of care.

The finding of the study regarding the low time of work by the professionals interviewed represents challenges regarding the qualification of the professionals to assume the responsibilities inherent in the control of tuberculosis at the local level, an issue that requires actions related to the link and integration between the Health Team and patients in the control of the disease, and that represents one of the challenges for the consistent expansion of FHS in the city of Rio de Janeiro.

Finally, the violence dimension seems to be incorporated into the daily life of the professionals who work in the Health Units. This question refers to the capacity for effective articulation between the public sectors involved and the formulation (and consolidation) of public policies that minimize the effect of this problem.

\section{REFERENCES}

1. Mendes EV. O cuidado das condições crônicas na atenção primária à saúde: o imperativo da consolidação da estratégia da saúde da família[Internet]. Organização Pan Americana de Saúde, Brasília (DF); 2012[cited 2016 Oct 16]. Available from: http://bvsms.saude.gov.br/ bvs/publicacoes/cuidado_condicoes_atencao_primaria_saude.pdf

2. Subsecretaria de Atenção Primária Vigilância e Promoção da Saúde, Secretaria Municipal de Saúde, Painel de Indicadores. Sistema de Login SUBPAV [Internet]. Rio de Janeiro(RJ); 2015 [cited 2016 Oct 16]. p. Painel de Indicadores. Available from: https://subpav.org

3. Malta DC, Santos MAS, Stopa SR, Vieira JEB, Melo EA, Reis AAC, et al. A Cobertura da Estratégia de Saúde da Família (ESF) no Brasil, segundo a Pesquisa Nacional de Saúde, 2013. Cienc Saude Colet. 2016;21(2):327-38. doi: 10.1590/1413-81232015212.23602015

4. Instituto Brasileiro de Geografia e Estatística-IBGE. Censo 2010 [Internet]. 2017 [cited 2017 Mar 15]. Available from: http://mapasinterativos. ibge.gov.br/atlas_ge/brasil1por1.html

5. Ministério do Planejamento Orçamento e Gestão (BR). Censo Demográfico 2010: Aglomerados Subnormais. Informações territoriais[Internet]. Rio de Janeiro (RJ). 2010 [cited 2017 Apr 16]. Available from: https://biblioteca.ibge.gov.br/visualizacao/ periodicos/552/cd_2010_agsn_if.pdf

6. Harzheim E, Lima KM, Hauser L. Pesquisa avaliativa sobre aspectos de implantação, estrutura, processo e resultados das clínicas da família na cidade do Rio de Janeiro (RJ) [Internet]. Porto Alegre (RS); 2013[cited 2017 Apr 16]. Available from: https://www.sbmfc.org.br/noticias/ pesquisa-da-ufrgs-avalia-as-clinicas-da-familia-na-cidade-do-rio-de-janeiro/

7. Bonomi AE, Wagner EH, Glasgow RE, VonKorff M. Assessment of chronic illness care (ACIC): a practical tool to measure quality improvement. Health Serv Res [Internet]. 2002 [cited 2018 Aug 7];37(3):791-820. Available from: http://www.ncbi.nlm.nih.gov/pubmed/12132606

8. Mendes EV. As redes de atenção à saúde. 2 edição. Organização Pan-Americana da Saúde. Brasília: Organização Pan-Americana da Saúde; 2011.549p.

9. Cavallieri F, Vial A. Coleção Estudos Cariocas: Favelas na cidade do Rio de Janeiro: O quadro populacional com base no Censo 2010 [Internet]. Rio de Janeiro; 2012 [cited 2017 Apr 16]. Available from: http://portalgeo.rio.rj.gov.br/estudoscariocas/download\%5C3190_ FavelasnacidadedoRiodeJaneiro_Censo_2010.PDF

10. Simões PP, Gameiro F, Nunes PC, Silva Jr AG, Scardua MT, Simas KBF. Expansão da atenção primária à saúde no município do Rio de Janeiro 
em 2010: o desafio do acesso e a completude das equipes de saúde da família. Rev Hosp Univ Pedro Ernesto [Internet]. 2017 [cited 2018 Aug 8];15(3):200-8. Available from: http://www.e-publicacoes.uerj.br/index.php/revistahupe/article/view/29445

11. Santos LJ, Paranhos MS. Family Health Teams workers in Rio de Janeiro: leadership aspects in a study on organizational climate. Cienc Saude Colet [Internet]. 2017[cited 2018 Aug 8];22(3):759-70. Available from: http://www.scielo.br/pdf/csc/v22n3/en_1413-8123-csc-22-03-0759.pdf

12. Seidl HMF, Vieira SP, Fausto MCR, Lima RCD, Gagno JL. Gestão do trabalho na atenção básica em saúde: uma análise a partir da perspectiva das equipes participantes do PMAQ-AB. Saúde Debate [Internet]. 2014 [cited 2018 Aug 8];38(spec):94-108. Available from: http://www. gnresearch.org/doi/10.5935/0103-1104.2014S008

13. Trindade LL, Pires DEP. Implications of primary health care models in workloads of health professionals. Texto Contexto Enferm [Internet]. 2013 [cited 2018 Aug 8];22(1):36-42. Available from: http://dx.doi.org/10.1590/S0104-07072013000100005

14. Bowen JL, Stevens DP, Sixta CS, Provost L, Johnson JK, Woods DM, et al. Developing measures of educational change for academic health care teams implementing the chronic care model in teaching practices. J Gen Intern Med [Internet]. 2010[cited 2018 Aug 8];25 Suppl 4(Suppl 4):S586-92. Available from: http://www.ncbi.nlm.nih.gov/pubmed/20737234

15. Sousa MD, Rocha AA, Pereira APS, Marques LFS, Oliveira MG. Motivação dos profissionais para ingresso e permanência na Estratégia Saúde da Família. In: Anais do CBMFC [Internet]. 2014 [cited 2017 Apr 16]. p. 190. Available from: https://www.cmfc.org.br/brasileiro/article/ view/1256

16. Souza RF, Abrahão AL. Reflexão sobre o processo de trabalho na Estratégia Saúde da Família. Rev Labor [Internet]. 2017[cited 2017 Apr 16];1(3):82-95. Available from: http://periodicos.ufc.br/index.php/Labor/article/view/9291

17. Souza MSPL, Aquino R, Pereira SM, Costa MCN, Barreto ML, Natividade M, et al. Fatores associados ao acesso geográfico aos serviços de saúde por pessoas com tuberculose em três capitais do Nordeste brasileiro. Cad Saude Publica [Internet]. 2015 [cited 2018 Aug 8];31(1):111-20. Available from: http://dx.doi.org/10.1590/0102-311X00000414

18. Souza FBA, Villa TCS, Cavalcante SC, Ruffino Netto A, Lopes LB, Conde MB. Peculiaridades do controle da tuberculose em um cenário de violência urbana de uma comunidade carente do Rio de Janeiro. J Bras Pneumol [Internet]. 2007[cited 2017 Mar 15];33(3):318-22. Available from: http://dx.doi.org/10.1590/S1806-37132007000300014

19. Paula HC, Aguiar AC. Abandono do tratamento da tuberculose na estratégia saúde da família: estudo qualitativo em uma área programática do Rio de Janeiro. Rev Baiana Saúde Pública [Internet]. 2013 [cited 2017 Apr 16];37(1). Available from: http://inseer.ibict.br/rbsp/index.php/ rbsp/article/view/356

20. Santiago Baldan S, Ferraudo AS, Andrade M. A eficácia da Estratégia Saúde da Família e do Tratamento Diretamente Observado no controle da Tuberculose. Rev Epidemiol e Control Infecção [Internet]. 2016 [cited 2018 Aug 8];6(4):169-74. Available from: https://online.unisc.br/ seer/index.php/epidemiologia/article/view/819 